\title{
Habitat and prey availability attributes associated with juvenile and early adult pallid sturgeon occurrence in the Missouri River, USA
}

\author{
Bryan D. Spindler ${ }^{1,5}$, Steven R. Chipps ${ }^{1, *}$, Robert A. Klumb ${ }^{1,2}$, Brian D. S. Graeb ${ }^{1,3}$, \\ Michael C. Wimberly ${ }^{1,4}$ \\ ${ }^{1}$ US Geological Survey, South Dakota Cooperative Fish and Wildlife Research Unit, \\ Department of Wildlife and Fisheries Sciences, South Dakota State University, Brookings, South Dakota 57007, USA \\ ${ }^{2}$ US Fish and Wildlife Service, Great Plains Fish and Wildlife Conservation Office, Pierre, South Dakota 57501, USA \\ ${ }^{3}$ Department of Wildlife and Fisheries Sciences, South Dakota State University, Brookings, South Dakota 57007, USA \\ ${ }^{4}$ Geographic Information Science Center of Excellence, Wecota Hall-506B, South Dakota State University, Brookings, \\ South Dakota 57007, USA \\ ${ }^{5}$ Present address: Minnesota Pollution Control Agency, St. Paul, Minnesota 55155, USA
}

\begin{abstract}
The pallid sturgeon Scaphirhynchus albus is a federally endangered species native to the Missouri and lower Mississippi Rivers, USA. As part of recovery efforts, over 360000 pallid sturgeon have been stocked into the Missouri River since 1994, and a standardized, long-term monitoring program was initiated in 2003. Understanding the distribution and habitat requirements of juvenile and early adult pallid sturgeon (fork length $<720 \mathrm{~mm}$, age $<10 \mathrm{yr}$ ) is an important goal of the monitoring and recovery programs. In this study, we collected information on habitat characteristics and prey availability from the upper Missouri River along the Nebraska-South Dakota border and compared these attributes between capture (present) and non-capture (absent) locations $(\mathrm{N}=59)$. To evaluate the relative influence of habitat and prey availability on pallid sturgeon occurrence, we examined several candidate models using an informationtheoretic approach. A prey availability model had the most support and included site-specific information on Diptera and Ephemeroptera abundance. A habitat-based model showed that juveniles and early adults were found in relatively deeper water and avoided areas where bottom velocities were greater than $1.2 \mathrm{~m} \mathrm{~s}^{-1}$. Although not as well supported as the prey-effects model (evidence ratio $=6.4$ ), habitat features also provided a plausible model for predicting occurrence. The models developed here could be used to evaluate pallid sturgeon habitat potential in the Missouri River basin and help guide future monitoring and conservation management of this endangered species.
\end{abstract}

KEY WORDS: Pallid sturgeon $\cdot$ Habitat model $\cdot$ Monitoring $\cdot$ Prey availability $\cdot$ Habitat selection Resale or republication not permitted without written consent of the publisher

\section{INTRODUCTION}

The pallid sturgeon Scaphirhynchus albus is a riverine species native to the Missouri and Mississippi Rivers, USA (Forbes \& Richardson 1905) that has been listed as federally endangered since 1990 (Dryer \& Sandvol 1993). The decline of pallid stur- geon populations has been associated with changes in the natural flow regime of the Missouri River due to impoundments and channelization (Hesse 1987, Hesse \& Sheets 1993). In the Missouri River, wild pallid sturgeon reach sexual maturity at Age 5 to $7 \mathrm{yr}$ for males and 10 to 13 yr for females (Keenlyne \& Jenkins 1993). Male and female captive broodstock in the 
hatchery first reach sexual maturity at Age 7 to $17 \mathrm{yr}$, with most fish mature at Age 9 to 12 yr (J. Powell pers. comm.). Loss of habitat, delayed sexual maturity, and low adult numbers have resulted in negligible natural reproduction of pallid sturgeon in many reaches of the Missouri River. Near term recovery efforts for the species have focused on stocking hatcheryreared fish to supplement the remnant wild population (Dryer \& Sandvol 1993, Krentz et al. 2005).

Annual stocking of hatchery-reared pallid sturgeon was implemented in 1994 in the lower Missouri River, and in 1998 in the upper Missouri River (Krentz et al. 2005). From 2000 through 2006, 4264 individuals were stocked into the $103 \mathrm{~km}$ segment of the Missouri River downstream of Fort Randall Dam in South Dakota and Nebraska, herein called the Fort Randall reach (Shuman et al. 2007). At stocking, the majority of fish $(83 \%)$ released were Age 1, with the remaining fish being 2 to 3 yr old (Shuman et al. 2007). Standardized sampling was started in the Fort Randall reach in 2003 (Welker \& Drobish 2010), and has resulted in the successful capture of sturgeon from all year classes stocked; total annual captures (25 to 60 fish $\mathrm{yr}^{-1}$ ) have increased every year since the sampling program began (Shuman et al. 2005, 2006, 2007).

Understanding factors that affect the distribution of juvenile pallid sturgeon represents an important part of the monitoring and assessment program (Welker \& Drobish 2010). Knowledge of habitat and prey requirements for juveniles is needed to aid in conservation management and identify potential early lifehistory bottlenecks (Bergman et al. 2008). The present study was designed to investigate habitat and prey relationships of juveniles and early adults in the Fort Randall reach of the Missouri River. Estimated survival rates for Age 1 pallid sturgeon stocked in the Missouri River ranged widely from 0.05 to 0.83 during the first 2 yr after release (Hadley \& Rotella 2009, Steffensen et al. 2010). As part of the monitoring and assessment program, information on water depth, water velocity, and substrate composition is routinely collected in areas where pallid sturgeon are captured (Welker \& Drobish 2010). These point measurements provide simple, baseline habitat characteristics that have been useful for characterizing macrohabitat attributes where pallid sturgeon occur (Reuter et al. 2009).

Several studies have used radio- and acoustictagged juvenile and adult pallid sturgeon to evaluate movement rates, behavior, and habitat use in the Missouri, Mississippi, and Atchafalaya Rivers (Snook et al. 2002, Hurley et al. 2004, Gerrity 2005, Jordan et al. 2006, Schramm \& Dunn 2008). In the Fort Randall reach, Jordan et al. (2006) found that median annual movement rates of juveniles ranged from 0.02 to $0.11 \mathrm{~km} \mathrm{~h}^{-1}$, with maximum diel movements of $0.37 \mathrm{~km} \mathrm{~h}^{-1}$ during daytime and $0.21 \mathrm{~km} \mathrm{~h}^{-1}$ at night. Telemetry results have also shown that both juveniles and adults prefer some areas over others and commonly aggregate at certain locations (Bramblett \& White 2001, Jordan et al. 2006). Elliott et al. (2004) assessed habitat selection at 15 sites in the Fort Randall reach, using the sonic-tagged juvenile pallid sturgeon from the study of Jordan et al. (2006), and found that the fish used sandy substrates with large dunes at water depths $0.8 \mathrm{~m}$ deeper than the average depths available. Elliott et al. (2004) found that pallid sturgeon used bottom water velocities in proportion to availability but were rarely found at velocities $>1.0 \mathrm{~m} \mathrm{~s}^{-1}$. A laboratory study also reported that juvenile pallid sturgeon selected sand substrates and greater depths than what was proportionally available (Allen et al. 2007).

Gut content analysis of juvenile pallid sturgeon in the Fort Randall reach has shown that aquatic invertebrates, especially Diptera (e.g. chironomids) and Ephemeroptera, comprise an important part of the diet and combined represent 55 to $75 \%$ of the diet composition by weight (Wanner et al. 2007, Grohs et al. 2009). This trend was particularly apparent for fish $\leq 500 \mathrm{~mm}$ fork length (FL). Consumption of fish prey was more prevalent among larger pallid sturgeon (>500 mm FL), although aquatic invertebrates remained a substantial part of the diet at over $35 \%$ wet weight (Grohs et al. 2009). Although these studies have yielded valuable information regarding prey use, there has been no effort to link pallid sturgeon occurrence to the distribution of aquatic macroinvertebrates in the Missouri River. To date, most work (i.e. telemetry studies) has focused on linking pallid sturgeon distribution to physical habitat characteristics (Snook et al. 2002, Elliott et al. 2004, Hurley et al. 2004, Gerrity 2005, Jordan et al. 2006).

Understanding the relative importance of prey availability and physical habitat for juvenile pallid sturgeon distribution in the Missouri River has important implications for conservation management. Knowing specific habitat conditions and macroinvertebrate densities that affect pallid sturgeon distribution could be used to identify areas where restoration efforts should be focused. In this study, we evaluated patterns of occurrence by juvenile and early adult pallid sturgeon in the Fort Randall reach relative to local habitat characteristics and prey availability. We hypothesized that pallid sturgeon would be more 
likely to occur in areas with both suitable habitat and relatively high prey abundance. To address this question, we used an information-theoretic approach to develop and compare models with both habitat and prey availability effects.

\section{MATERIALS AND METHODS}

\section{Study site}

Pallid sturgeon habitat was studied in the $103 \mathrm{~km}$ segment of the Missouri River downstream of Fort Randall Dam, which forms the border between South Dakota and Nebraska (Fig. 1). The Fort Randall reach is an impounded portion of the Missouri River that begins at the Fort Randall Dam, near Pickstown, South Dakota (river km [rkm] 1402) and extends to Gavin's Point Dam, near Yankton, South Dakota (rkm 1299). This reach is unique because it can be divided into riverine $(\sim 55 \mathrm{rkm})$, delta $(\sim 24 \mathrm{rkm})$, and reservoir ( $\sim 24 \mathrm{rkm})$ habitats. The delta area is characterized by a large, braided channel formed by sediment inputs from the Niobrara River (rkm 1350; Fig. 1). Discharge from Fort Randall Dam is regulated by the United States Army Corps of Engineers (USACE) for flood control and hydroelectric power production. Water levels can fluctuate as much as $1 \mathrm{~m} \mathrm{~d}^{-1}$ in the upper riverine reach due to power production demands (Klumb 2007).

A total of 8 river segments (3.2 km each) representing the riverine $(\mathrm{n}=4)$ and delta $(\mathrm{n}=4)$ areas of the Fort Randall reach were chosen for intensive habitat and macroinvertebrate sampling (Spindler 2008; Fig. 1). Representative river segments were chosen based on previous sampling efforts in the Fort Randall reach (US Fish and Wildlife Service, USFWS, unpublished data), and where pallid sturgeon random sampling was scheduled to occur during the summer of 2006. However, due to logistic constraints, not all reaches sampled for pallid sturgeon were sampled for habitat and prey availability. Upstream boundaries of the 4 sample segments in the riverine portion were located near rkm 1390, 1376, 1361, and 1355. The 4 sampling reaches in the delta area were located at rkm 1350, 1345, 1337, and 1331.

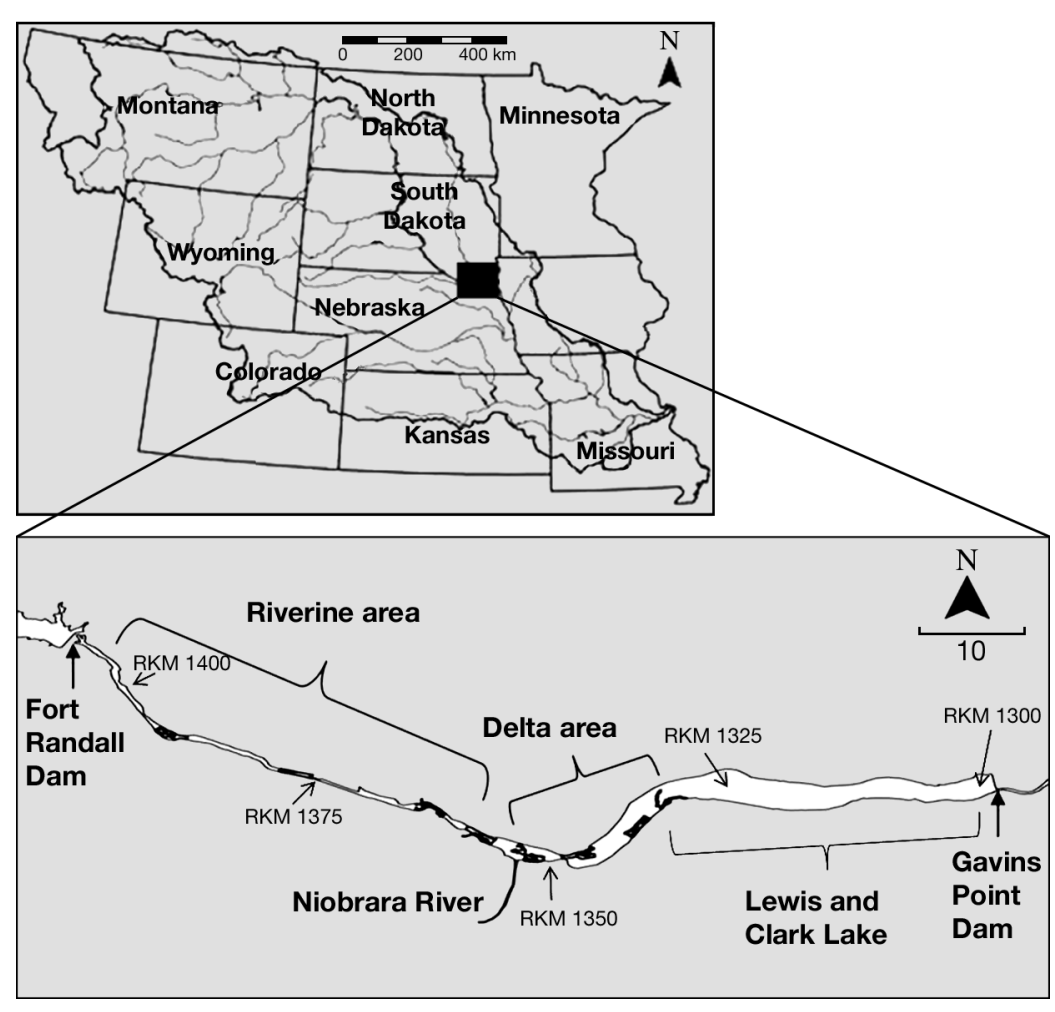

Fig. 1. Missouri River watershed (top panel) and study area located between Fort Randall and Gavin's Point dams, South Dakota and Nebraska. Sample areas in 2006 for juvenile and early adult pallid sturgeon were located in the riverine and delta areas of the reach (bottom panel). Shaded areas represent the 8 sampling segments $(3.2 \mathrm{~km}$ each) where physical habitat and prey availability sampling was conducted in 2006

\section{Presence-absence sampling}

Fish sampling

Pallid sturgeon were sampled in the riverine and delta regions of the Fort Randall reach (Fig. 1) in 2006 using drifted trammel nets $(\mathrm{n}=39)$ or otter trawls $(\mathrm{n}=20$ ) deployed during daylight hours. Trammel net surveys occurred in late July and early September, while otter trawl surveys occurred in late June and early August. Detailed gear specifications and deployments are described in a standardized sampling protocol for the riverwide monitoring program (Welker \& Drobish 2010). Trammel nets (38.1 m length) were constructed of multifilament nylon netting with a $2.4 \mathrm{~m}$ deep inner wall and a $1.8 \mathrm{~m}$ deep outer wall with a $2.5 \mathrm{~cm}$ inner bar mesh and $20.3 \mathrm{~cm}$ outer bar mesh. Trammel nets were drifted from upstream to downstream for a maximum distance of $300 \mathrm{~m}$ and minimum of $75 \mathrm{~m}$. Otter trawls (total length $7.6 \mathrm{~m}$ ) were constructed of polyethylene netting with 
an outer chafing body of $19 \mathrm{~mm}$ bar mesh and a $6.3 \mathrm{~mm}$ bar mesh inner net attached $4.6 \mathrm{~m}$ from the mouth and terminating with a $406 \mathrm{~mm}$ cod end opening. While towed, the trawl width of $4.8 \mathrm{~m}$ width and $0.91 \mathrm{~m}$ height was kept open with $762 \mathrm{~mm}$ long by $381 \mathrm{~mm}$ wide spreader doors (Innovative Nets Systems). Each deployment of the trawl was pulled slightly faster than the current velocity along the bottom of the river from upstream to downstream for a targeted distance of $300 \mathrm{~m}$ and a minimum of $75 \mathrm{~m}$. As part of the standardized sample strategy, 10 river bends were randomly selected, with 8 trammel net drifts and benthic trawls expended per bend. Global positioning system (GPS) coordinates were obtained at the start and endpoint of each deployment, and sample distance was calculated using a WAAS enabled Garmin GPSMAP 168 echo sounder or Garmin GPSMAP76 handheld GPS unit (precision of 3 to $10 \mathrm{~m})$.

\section{Site mapping}

The use of drifting nets and trawls precluded us from determining the exact location at which a pallid sturgeon was captured along a sampled transect. In an effort to better characterize and map fish sampling locations, we used ArcMap 9.2 (ESRI) to construct a $300 \mathrm{~m}$ buffer $\left(\sim 0.42 \mathrm{~km}^{2}\right)$ in a geographic information system (GIS) that encompassed the starting location, linear sample path, and endpoint of each gear deployment. We chose $300 \mathrm{~m}$ as a buffer around each transect because (1) it conservatively approximated where the fish likely was, based on diel movements of juveniles as determined by radio telemetry (Jordan et al. 2006) and (2) it would be more likely to include the actual area used by a sturgeon prior to capture. In cases where buffer areas for a non-capture location (i.e. absence) overlapped with a capture event (i.e. presence), we eliminated the non-capture location from the analysis to facilitate coding of fish sample locations as either presence or absence.

\section{Model variables}

Physical habitat

We sampled macrohabitat attributes in each of the eight $3.2 \mathrm{~km}$ river segments of the Fort Randall reach (Fig. 1). Water depth and velocity were measured in July 2006 using a boat-mounted 1.5 MHz SonTek
RiverCat Acoustic Doppler Profiler (ADP; SonTek/ YSI). In the main channel, ADP data were collected from bank to bank along transects perpendicular to the current at a spacing of 100 to $150 \mathrm{~m}$. Secondary channels were sampled using diagonal cross-channel transects to maximize sampling efficiency and facilitate boat navigation. The average ping interval for water depth and water velocity measurements was $10 \mathrm{~s}$. Water velocity was measured starting $0.5 \mathrm{~m}$ off the river bottom (due to depth limitation of the ADP's frequency) on a vertical profile with cell height set to $25 \mathrm{~cm}$. For each ping interval, a realtime differentially corrected GPS position was obtained using a Trimble GPS receiver linked to the ADP unit (precision $<1 \mathrm{~m}$ ).

Sediment was collected using a $0.3 \mathrm{~m}$ long $\times$ $10.8 \mathrm{~cm}$ diameter cylindrical Hess sampler. Substrate particle size, expressed as percent composition, was qualitatively estimated in the field using the size classifications of Wentworth (1922) and Threader et al. (1998). Sediment samples were collected at 3 locations along transects spaced $300 \mathrm{~m}$ apart. For each transect, we collected sediment samples at $25 \%$ of the channel width near the left and right banks, and in the center of the main channel. For narrow secondary channels, sediment samples were collected in the center every $300 \mathrm{~m}$. Latitude and longitude were recorded for all sample locations.

\section{Prey abundance}

An index of aquatic macroinvertebrate abundance was obtained for each $3.2 \mathrm{~km}$ segment in June and August of 2006 using a $0.5 \mathrm{~m}$ diameter, $3 \mathrm{~m}$ long, $500 \mu \mathrm{m}$ mesh conical drift net (Cummins 1962) attached to a $22.7 \mathrm{~kg}$ weight. Drift nets were deployed along transects spaced $300 \mathrm{~m}$ apart at points near $25 \%$ of the channel width near the left and right banks, and in the middle of the main river channel; latitude and longitude were recorded for all sample locations. Drift net samples in secondary channels were collected in the middle of the channel every $300 \mathrm{~m}$. The net was deployed within $0.25 \mathrm{~m}$ of the river bottom for 2 to 8 min depending on the suspended detritus load. The volume of water sampled was measured using a flow meter affixed to the center of the net mouth. Macroinvertebrates were preserved in $90 \%$ ethanol containing rose bengal dye. In the laboratory, aquatic invertebrates were sorted, enumerated, and identified to family (Pennak 1978, Merritt \& Cummins 1996). Macroinvertebrate abundance estimates were expressed as volumetric density (ind. $\mathrm{m}^{-3}$ ). 
The extent to which pallid sturgeon feed on drift or extract benthic invertebrates buried in the substrate is unknown. Work done by Grohs (2008) showed that the relative abundance of mayflies and midges collected from drift nets was positively correlated to that quantified from non-drift samples (Surbers and sweep nets) from 6 sites in the Missouri River. Thus, relative differences in prey abundance among sites should be reasonably characterized by drift net samples, and provide a robust index of prey availability.

\section{GIS mapping: habitat and prey abundance}

A GIS was used to develop digital maps for each river segment from measured habitat and prey variables using ArcMap 9.2. Shoreline boundaries for each river segment were digitized using simplified contours derived from 2006 light detection and ranging (LIDAR) elevation data collected by the USACE and was adjusted for mean water level for June through September of 2006. Maps were corrected for missing data by eliminating shallow water areas less than $0.5 \mathrm{~m}$ deep that prohibited boat navigation and sampling.

Interpolated maps of each measured physical habitat and prey attribute were calculated from measured field point data by ordinary kriging (Krige 1966) with anisotropy (i.e. variance dependent on direction) or inverse distance weighting methods using the Geostatistical Analyst Tool in ArcMap 9.2. Three attributes of physical habitat that are known to affect pallid sturgeon location based on previous studies (Elliott et al. 2004, Allen et al. 2007) were mapped in each reach and included (1) water depth, (2) bottom water velocity, and (3) substrate composition. Two indices of food availability, viz. dipteran and ephemeropteran abundance, were chosen based on previous diet studies (Grohs et al. 2009). A $20 \mathrm{~m}$ grid cell size was used for each map because it maximized processing efficiency and resolution. The best interpolation method for each variable was chosen based on the lowest mean square error from cross-validation calculated by comparing predicted to observed values. Ordinary kriging was used with the ADP data to create maps for water depth and near-bottom water velocity for each $3.2 \mathrm{~km}$ sample river reach. Inverse distance weighting was used to create interpolated maps of invertebrate abundance and substrate composition based on the drift sample locations. Maps for mean summer macroinvertebrate abundance were derived by averaging the abundance of dipterans and ephemeropterans for June and August after interpolation.
Maps developed for the fish sampling transects along with their $300 \mathrm{~m}$ buffers were overlain on the interpolated physical habitat and invertebrate abundance data (surfaces) to derive metric values for analysis. Macrohabitat and prey abundance metrics were calculated from their respective interpolated maps for each fish sampling location and included mean water depth $(\mathrm{m})$, proportion of sand substrate, proportion of total area with bottom water velocity $>1.2 \mathrm{~m} \mathrm{~s}^{-1}$, mean Diptera abundance (ind. $\mathrm{m}^{-3}$ ), and mean Ephemeroptera abundance (ind. $\mathrm{m}^{-3}$ ).

\section{Model development}

We developed a global logistic regression model relating pallid sturgeon occurrence to habitat characteristics and prey availability. For the dependent variable in the logistic regression analysis, we coded sites based on a successful (value $=0$ ) or unsuccessful (value $=1$ ) capture of a pallid sturgeon. To evaluate inter-relationships among predictor variables, we used multicollinearity diagnostics to calculate variance inflation factors (VIFs) for each variable. We adjusted linear combinations of variables by the weight matrix used in the maximum likelihood algorithm and removed any variable with a VIF > 5 (Allison 1999). We then conducted a Hosmer-Lemeshow test (Hosmer \& Lemeshow 1989) to evaluate model fit, and if model assumptions were met $\left(p>0.10, \chi^{2}\right.$ goodness of fit test), the relative rank of competing models was assessed using an Akaike information criterion (AIC) approach (Burnham \& Anderson 1998). Because we were interested in models with habitat and/or prey availability effects, the AIC approach allowed us to compare the relative strength of competing models (Rich et al. 2003).

The relative importance of individual model variables was evaluated using scaled odds ratios as described by Rich et al. (2003), where odds ratios were calculated by raising e to the value of the $i$ th logistic regression coefficient and are given as $\mathrm{e}^{\hat{\beta} i}$ where $\hat{\beta} i$ is the parameter coefficient estimated from logistic regression analysis. In this form, the odds ratios are based on a single-unit change that may not reflect the magnitude of difference between sites (i.e. presence versus absence). To make these units more biologically meaningful (i.e. larger or smaller), we multiplied parameter coefficients by a constant $(C)$ which resulted in a 'scaled' odds ratios equal to $\mathrm{e}^{C \times \hat{\beta} i}$. Here, $C$ was derived by calculating the median value of each variable for sites where pallid sturgeon were present or absent, and then taking the difference 
between these values, rounded to the nearest unit of 5 (Rich et al. 2003). For each significant predictor variable in the composite model(s), we calculated a $95 \%$ confidence interval $\left(\mathrm{e}^{C \times \hat{\beta} i \pm 1.96 \times C \times \mathrm{SE} \hat{\beta} i}\right)$ and evaluated the importance of each parameter by assessing the magnitude of values at either the lower (positive coefficient) or the upper bound (negative coefficient) (Rich et al. 2003).

\section{RESULTS}

\section{Pallid sturgeon captures}

In 2006, 25 juvenile and early adult pallid sturgeon, all of hatchery origin based on the presence of passive integrated transponder (PIT) tags, were captured (mean FL $=491 \mathrm{~mm}$; range 330 to $720 \mathrm{~mm}$ ) from 10 of the 59 sites sampled (Table 1). Seven sturgeon (mean FL $=407 \mathrm{~mm}$ ) were captured from riverine habitats, and 18 (mean FL = $546 \mathrm{~mm}$ ) were captured from the delta region. Multiple captures of pallid sturgeon ( $>1$ ind. location ${ }^{-1} \mathrm{~d}^{-1}$ ) occurred at 5 sites; on 1 date, 12 fish were captured from a single location in the delta region of the Fort Randall reach. Mean overall catch per unit effort (CPUE) of pallid sturgeon was similar for trammel nets $(0.044$ fish per $100 \mathrm{~m})$ and otter trawls (0.051 fish per $100 \mathrm{~m}$; $t$-test, $\mathrm{df}=12$, $t=2.17, \mathrm{p}=0.84)$. In general, CPUE for trammel nets was similar in the riverine and delta habitats. However, CPUE for otter trawls was noticeably higher in the delta compared to the riverine reach (Table 1).

\section{Model variables}

Measures of habitat attributes, averaged for capture $(\mathrm{n}=10)$ and non-capture $(\mathrm{n}=49)$ areas, revealed that pallid sturgeon were more likely to occur in areas with deeper water depth, slower bottom veloc-
Table 2. Mean values for habitat attributes and macroinvertebrate prey abundance at Missouri River sampling sites where juvenile and early adult pallid sturgeon were present or absent. Values in parentheses represent $1 \mathrm{SE}$

\begin{tabular}{|lcc|}
\hline Variable & $\begin{array}{c}\text { Present } \\
(\mathrm{n}=10)\end{array}$ & $\begin{array}{c}\text { Absent } \\
(\mathrm{n}=49)\end{array}$ \\
\hline Habitat & & \\
Mean depth (m) & $3.09(0.25)$ & $2.73(0.06)$ \\
$\begin{array}{l}\text { Substrate (proportion sand) } \\
\text { Bottom velocity } \\
\left.\quad \text { proportion }>1.20 \mathrm{~m} \mathrm{~s}^{-1}\right)\end{array}$ & $0.002(0.03)$ & $0.81(0.02)$ \\
Prey & & $0.049(0.01)$ \\
$\begin{array}{l}\left.\text { Diptera (ind. } \mathrm{m}^{-3}\right) \\
\left.\text { Ephemeroptera (ind. } \mathrm{m}^{-3}\right)\end{array}$ & $0.65(0.16)$ & $0.37(0.07)$ \\
\hline
\end{tabular}

ity, and increased sand substrate (Table 2). Sturgeon were also associated with high abundance of aquatic macroinvertebrates; mean larval Diptera abundance was 1.9 times higher and Ephemeroptera abundance was 1.7 times higher in areas with pallid sturgeon compared to non-capture areas (Table 2).

Multicollinearity diagnostics indicated that substrate composition (i.e. proportion of sand) was strongly correlated with Diptera density, and when included in the analysis, generated a high VIF $(>520)$. Because sand substrate was positively related to Diptera density, we excluded it from subsequent analysis. We omitted the sand substrate variable because (1) sand was a predominant substrate type at all sites, with average percent composition exceeding $80 \%$, and (2) Diptera density was a more influential variable in explaining differences between capture and non-capture sites ( $t$-test, $t=-3.01, \mathrm{p}=0.004)$.

After excluding substrate composition from the analysis, the global model included 2 habitat effects (water depth and bottom velocity) and 2 measures of prey availability (Diptera and Ephemeroptera) that provided an adequate fit to the data (HosmerLemeshow goodness-of-fit statistic $\chi^{2}$ $=2.15, \mathrm{df}=8, \mathrm{p}=0.97$; Table 3 ). Thus, we evaluated the relative strength of competing models at predicting the presence of pallid sturgeon in the Fort Randall reach. The model containing prey effects was the best overall model for predicting presence (Table 4). However, the global model and the habitat-only model had sufficiently high Akaike weights (evidence ratios 1.8 to 6.4 ) that they could not be ruled out. 
Table 3. Variables and parameter estimates used in the composite logistic regression model for juvenile and early adult pallid sturgeon occurrence. Scaling factors and scaled odds ratios (OR) are explained in 'Materials and methods'. CI: confidence interval

\begin{tabular}{|lrrccc|}
\hline Variable & Estimate & SE & $\begin{array}{c}\text { Scaling } \\
\text { factor }\end{array}$ & $\begin{array}{c}\text { Scaled } \\
\text { OR }\end{array}$ & $\begin{array}{c}\text { 95\% CI for } \\
\text { scaled OR }\end{array}$ \\
\hline Intercept & -5.23 & 2.42 & & & \\
Water depth & 0.60 & 0.76 & 0.35 & 1.23 & $(0.73,2.07)$ \\
Bottom velocity & -45.39 & 46.04 & 0.005 & 0.79 & $(0.50,1.25)$ \\
Diptera & 0.66 & 0.31 & 0.110 & 1.07 & $(0.54,2.11)$ \\
Ephemeroptera & 1.24 & 0.66 & 0.035 & 1.04 & $(0.66,1.65)$ \\
\hline
\end{tabular}

Pallid sturgeon occurrence was positively associated with increased water depth and macroinvertebrate density and negatively associated with the proportion of area with bottom water velocities $>1.20 \mathrm{~m}$ $\mathrm{s}^{-1}$ (Fig. 2). A $0.35 \mathrm{~m}$ increase in water depth was as-
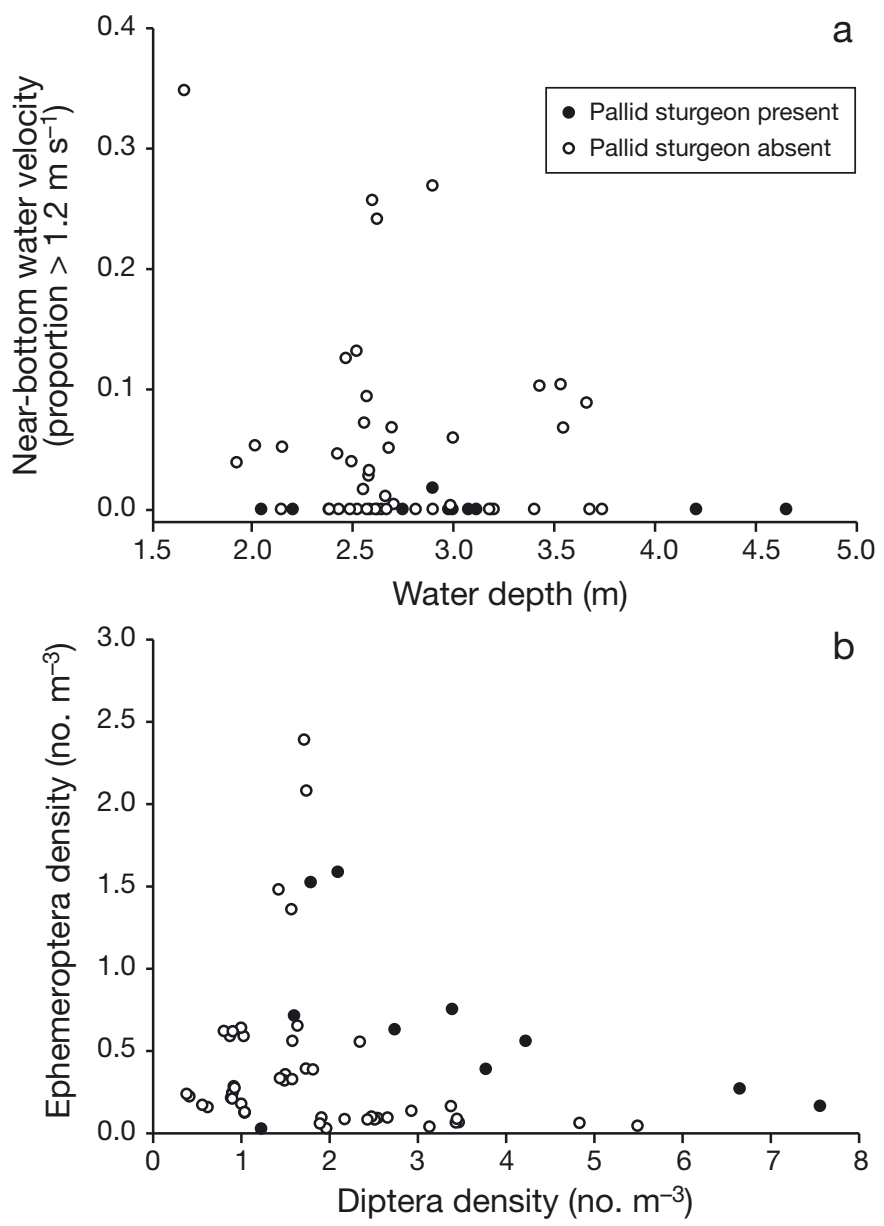

Fig. 2. Scaphirhynchus albus. Presence or absence of juvenile and early adult pallid sturgeon in the Fort Randall reach of the Missouri River in relation to (a) bottom velocity and water depth and (b) macroinvertebrate abundance
Table 4. Model results summarizing Akaike weights $\left(w_{i}\right)$ for logistic regression models containing habitat measures (water depth, bottom velocity), prey abundance (Diptera, Ephemeroptera), or both (water depth, bottom velocity, Diptera, and Ephemeroptera) in relation to juvenile and early adult pallid sturgeon occurrence in the Fort Randall reach of the Missouri River. N: number of gear deployments, $\mathrm{K}$ : number of parameters, AICc: Akaike information criterion with a correction for finite sample sizes, $\Delta_{i}$ : delta AIC

\begin{tabular}{|lllllll|}
\hline Model & N & K & AICc & $\Delta_{i}$ & $W_{i}$ \\
\hline $\begin{array}{l}\text { Habitat variables } \\
\text { Water depth, bottom velocity }\end{array}$ & 59 & 4 & 49.06 & 3.66 & 0.09 \\
$\begin{array}{l}\text { Prey abundance } \\
\text { Diperta, Ephemeroptera }\end{array}$ & 59 & 4 & 45.40 & 0.00 & 0.58 \\
$\begin{array}{l}\text { Global } \\
\text { Water depth, bottom velocity, }\end{array}$ & 59 & 6 & 46.60 & 1.10 & 0.32 \\
$\begin{array}{l}\text { Diptera, Ephemeroptera } \\
\text { alog(odds of occurrence) }\end{array}$ \\
$\begin{array}{l}56.08(\text { bottom velocity) } \\
\text { blog(odds of occurrence) } \\
1.55(\text { Ephemeroptera) }\end{array}$
\end{tabular}

sociated with at least a $36 \%(1 / 0.73)$ increase in predicted odds of an occurrence. Similarly, an increase of 0.11 Diptera $\mathrm{m}^{-3}$ was associated with an $82 \%(1 / 0.54)$ increase in the odds of pallid sturgeon presence. Bottom water velocity greater than $1.20 \mathrm{~m} \mathrm{~s}^{-1}$ was negatively associated with occurrence; a 0.005 decrease in the proportion of bottom velocities $>1.20 \mathrm{~m} \mathrm{~s}^{-1}$ was associated with at least a $25 \%(1.25 / 1)$ increase in the predicted odds of an occurrence.

\section{DISCUSSION}

The approach used in our study is unique in that it is the first attempt to evaluate the relative strength of habitat and prey availability effects on the occurrence of juvenile and early adult pallid sturgeon in the Missouri River. Unlike other studies, the approach used here has several advantages: (1) it includes information from capture and non-capture locations, thus enabling us to compare and contrast attributes that are important to pallid sturgeon; (2) most input data (i.e. fish collection and habitat) are routinely collected as part of the basin-wide monitoring and assessment program; and (3) it can be used to generate a probability of occurrence for specific locations that can help identify potential sampling locations for future monitoring to recapture greater numbers of fish and improve estimates of survival rates, especially for young fish.

Like other studies, we found that the occurrence of juveniles and early adults was more likely in areas with deeper water $(>3 \mathrm{~m})$ and a higher proportion of 
sand substrate, and that they generally avoided areas with bottom velocities $>1.20 \mathrm{~m} \mathrm{~s}^{-1}$. Previous studies have shown that water depth $(>2 \mathrm{~m})$ and sand substrate are positively associated with wild adult pallid sturgeon habitat selection in the Missouri River in Montana and North Dakota (Bramblett \& White 2001). Using a habitat selectivity index, Reuter et al. (2009) showed that in unchannelized reaches of the lower Missouri River, pallid sturgeon positively selected water depths $>3 \mathrm{~m}$ and water velocities $<1 \mathrm{~m} \mathrm{~s}^{-1}$. In the middle Mississippi River, wild adult pallid sturgeon frequently selected deep main channel habitat rather than shallow areas (Hurley et al. 2004). Concordance of our study to the other studies of pallid sturgeon indicates that water depths $>2 \mathrm{~m}$ and water velocities $<1 \mathrm{~m} \mathrm{~s}^{-1}$ are important habitat features for this species.

Index measures of prey abundance were equally (if not more) important than habitat features at predicting the occurrence of pallid sturgeon. Although evidence ratios calculated from AIC analysis provide only relative measures of model strength (Burnham \& Anderson 1998), prey availability effects (i.e. preyonly model) were clearly important predictors of occurrence. The evidence ratio comparing our prey effects model to the habitat effects model was 6.4 (0.58/0.09). Thus, quantifying Diptera and Ephemeroptera abundance in areas $\left(\sim 0.4 \mathrm{~km}^{2}\right)$ with water depths $>2 \mathrm{~m}$ and water velocities $<1 \mathrm{~m} \mathrm{~s}^{-1}$ could provide a reliable method for comparing the relative potential of pallid sturgeon occurrence in the Fort Randall reach. Although this approach would not be considered a rapid assessment because of the invertebrate sample processing, it should be an important consideration for the assessment of habitat quality for pallid sturgeon. Moreover, water depth and bottom velocity can be quickly quantified in real time using an ADP to identify areas with suitable pallid sturgeon habitat for invertebrate sampling.

Prey fish are known to be an important component of the diets of large juvenile and early adult pallid sturgeon $>700 \mathrm{~mm}$ in the Missouri River (Gerrity et al. 2006, Grohs et al. 2009). Diets of pallid sturgeon (>500 mm FL) in the Fort Randall reach also contained prey fish, mainly silver chubs Macrhybopsis storeriana, emerald shiners Notropis atherinoides, and johnny darters Etheostoma nigrum (Wanner et al. 2007, Grohs et al. 2009). We focused on juveniles and early adults across a size range that encompasses an ontogenetic diet shift from macroinvertebrates to fish prey, a transition hypothesized to increase mortality (USFWS 2006). Because the occurrence of fish in the diet of pallid sturgeon increases with body size (Grohs et al. 2009), future efforts to model the occurrence of pallid sturgeon should consider measures of prey fish abundance in conjunction with physical habitat features (Gerrity et al. 2006, Klumb 2007). Invertebrate abundance could also be an indirect measure of prey quality by attracting prey fish that also consume invertebrates. These prey fish could then be beneficial for adult pallid sturgeon that are piscivorous (Carlson et al. 1985).

The models developed here could be used to efficiently target areas for pallid sturgeon sampling. Despite a relatively small sample of captures, there appears to be a link to both prey and habitat characteristics. Multiple captures at single locations (i.e. $50 \%$ of the sites), although only coded as 'present' in our analysis, suggest that the habitat and prey availability metrics identified here have a strong influence on sturgeon distribution in the river. Because our study encompassed only $1 \mathrm{yr}$, future research should assess how these habitat and macroinvertebrate prey relationships change seasonally and annually to better guide species recovery and ecosystem restoration efforts. A targeted sampling approach that focuses on areas with a relatively high probability of occurrence may improve capture success, enhancing our ability through increased sample size to monitor growth, survival, and abundance as well as reduce variation in catch rate. Such focused sampling efforts might lead to higher catch rates and/or guide stocking efforts so that hatchery-reared pallid sturgeon have the best chance of survival after release.

Acknowledgements. We thank D. Shuman, W. Stancill, and G. Wanner from the USFWS, Great Plains Fish and Wildlife Conservation Office, Pierre, South Dakota, for technical assistance and data collection. Funding for the long-term standardized monitoring program was provided by the USACE Northwestern Division Omaha District Missouri River Recovery Program, Yankton, South Dakota. We also thank N. Pool and C. Warner for assisting with data collection and sample processing, and B.J. Bauer and P. Braaten for helpful comments on previous versions of this manuscript. Funding for this project was provided by the South Dakota Department of Game, Fish \& Parks through the State Wildlife Grants Program (Project T-24-R, study no. 2424) and the US Department of Energy-Western Area Power Administration. The US Geological Survey, South Dakota Cooperative Fish and Wildlife Research Unit, is jointly supported by the US Geological Survey, the South Dakota Department of Game, Fish \& Parks, South Dakota State University, the Wildlife Management Institute, and the USFWS. Any use of trade names is for descriptive purposes only and does not imply endorsement by the Federal Government. All research work with pallid sturgeon was conducted in accordance with institutional, national, and international guidelines concerning the use of animals in research and/or the sampling of endangered species. 


\section{LITERATURE CITED}

Allen TC, Phelps QE, Davinroy RD, Lamm DM (2007) A laboratory examination of substrate, water depth, and light use at two water velocity levels by individual juvenile pallid (Scaphirhynchus albus) and shovelnose (Scaphirhynchus platorynchus) sturgeon. J Appl Ichthyol 23: 375-381

Allison PD (1999) Logistic regression using the SAS system: theory and application. SAS Institute, Cary, NC

Bergman HL, Boelter AM, Parady K, Fleming C and others (2008) Research needs and management strategies for pallid sturgeon recovery. Proceedings of a Workshop held July 31-August 2, 2007, St. Louis, Missouri. Final Report to the U.S. Army Corps of Engineers. William D. Ruckelshaus Institute of Environment and Natural Resources, University of Wyoming, Laramie, WY

> Bramblett RG, White RG (2001) Habitat use and movements of pallid and shovelnose sturgeon in the Yellowstone and Missouri Rivers in Montana and North Dakota. Trans Am Fish Soc 130:1006-1025

Burnham KP, Anderson DR (1998) Model selection and inference: a practical information theoretic approach. Springer-Verlag, New York, NY

Carlson DM, Pflieger WL, Trial L, Haverland P (1985) Distributions, biology and hybridization of Scaphirhynchus albus and Scaphirhynchus platorynchus in the Missouri and Mississippi rivers. Environ Biol Fishes 14:51-59

Cummins KW (1962) An evaluation of some techniques for the collection and analysis of benthic samples with special emphasis on lotic waters. Am Midl Nat 67:477-504

Dryer MP, Sandvol AJ (1993) Pallid sturgeon, Scaphirhynchus albus, recovery plan. Department of the Interior US Fish and Wildlife Service, Washington, DC

Elliott CE, Jacobson RB, DeLonay AJ (2004) Physical aquatic habitat assessment, Fort Randall segment of the Missouri River, Nebraska and South Dakota. Open file report 2004-1060. United States Geological Survey, Columbia Environmental Research Center, Columbia, MO

Forbes SA, Richardson RE (1905) On a new shovelnose sturgeon from the Mississippi River. Bull Ill State Lab Nat Hist 7:39-44

Gerrity PC (2005) Habitat use, diet, and growth of hatcheryreared juvenile pallid sturgeon and indigenous shovelnose sturgeon in the Missouri River above Fort Peck Reservoir. MS thesis, Montana State University, Bozeman, MT

Gerrity PC, Guy CS, Gardner WM (2006) Juvenile pallid sturgeon are piscivorous: a call for conserving native cyprinids. Trans Am Fish Soc 135:604-609

Grohs KL (2008) Macroinvertebrate composition and patterns of prey use by juvenile pallid sturgeon (Scaphirhynchus albus) in the Missouri River, South Dakota and Nebraska. MS thesis, South Dakota State University, Brookings, SD

Grohs KL, Klumb RA, Chipps SR, Wanner GA (2009) Ontogenetic patterns in prey use by pallid sturgeon in the Missouri River, South Dakota and Nebraska. J Appl Ichthyol 25(Suppl 2):48-53

Hadley GL, Rotella JJ (2009) Upper basin pallid sturgeon survival estimation project. Final Report prepared for the Upper Basin Pallid Sturgeon Workgroup. Montana State University, Bozeman, MT

Hesse LW (1987) Taming the wild Missouri River: What has it cost? Fisheries 12:2-9
Hesse LW, Sheets W (1993) The Missouri River hydrosystem. Fisheries 18:5-14

Hosmer DW Jr, Lemeshow S (1989) Applied logistic regression. Wiley, New York, NY

> Hurley KL, Sheehan RJ, Heidinger RC, Wills PS, Clevenstine B (2004) Habitat use by middle Mississippi River pallid sturgeon. Trans Am Fish Soc 133:1033-1041

- Jordan GR, Klumb RA, Wanner GA, Stancill WJ (2006) Poststocking movements and habitat use of hatchery-reared juvenile pallid sturgeon in the Missouri River below Fort Randall Dam, South Dakota and Nebraska. Trans Am Fish Soc 135:1499-1511

Keenlyne KD, Jenkins LG (1993) Age at sexual maturity of pallid sturgeon. Trans Am Fish Soc 122:393-396

Klumb RA (2007) Shallow water fish communities in the Missouri River downstream of Fort Randall and Gavins Point dams in 2003 and 2004 with emphasis on Asian carps. Prepared for the Aquatic Nuisance Species Coordinator, U.S. Fish and Wildlife Service - Region 6. United States Fish and Wildlife Service Great Plains Fish and Wildlife Management Assistance Office, Pierre, SD (available at www.fws.gov/greatplainsfishandwildlife/)

Krentz S, Holm R, Bollig H, Dean J and others (2005) Pallid sturgeon spawning and stocking summary report, 1992-2004. United States Fish and Wildlife Service. Missouri River Fish and Wildlife Management Assistance Office, Bismarck, ND (available at www.fws.gov/ moriver/)

Krige DG (1966) Two-dimensional weighted moving average trend surfaces for ore valuation. J S Afr Inst Min Metall 66:13-38

Merritt RW, Cummins KW (1996) An introduction to the aquatic insects of North America, 3rd edn. Kendall Publishing Company, Dubuque, IA

Pennak RW (1978) Fresh-water invertebrates of the United States, 2nd edn. Wiley Interscience Publishing Company, New York, NY

Reuter JM, Jacobson RB, Elliot CM, DeLonay AJ (2009) Assessment of lower Missouri River physical aquatic habitat and its use by adult sturgeon (Scaphirhynchus), 2005-07. US Geological Survey Scientific Investigations Report 2009-5121. United States Geological Survey, Columbia Environmental Research Center, Columbia, $\mathrm{MO}$

Rich CF Jr, McMahon TE, Rieman BE, Thompson WL (2003) Local-habitat, watershed, and biotic features associated with bull trout occurrence in Montana streams. Trans Am Fish Soc 132:1053-1064

Schramm HL, Dunn WO III (2008) Summer movement and habitat use of pallid sturgeon in the Old River and Atchafalaya River. Annual report to US Fish and Wildlife Service. Mississippi Cooperative Fish and Wildlife Research Unit, Mississippi State, Jackson, MS

Shuman DA, Wanner GA, Klumb RA, McAlpin ST (2005) 2004 Annual report. Pallid sturgeon population assessment and associated fish community monitoring for the Missouri River: segments 5 and 6. Prepared for the U.S. Army Corps of Engineers Northwest Division Kansas City and Omaha Districts. US Fish and Wildlife Service, Great Plains Fish and Wildlife Management Assistance Office, Pierre, SD (available at www.fws.gov/ greatplainsfishandwildlife/)

Shuman DA, Wanner GA, Klumb RA, Stancill WJ (2006) 2005 Annual report. Pallid sturgeon population assessment project and associated fish community monitoring 
for the Missouri River: segments 5 and 6. Prepared for the US Army Corps of Engineers Northwest Division. US Fish and Wildlife Service, Pierre, SD (available at www. fws.gov/greatplainsfishandwildlife/)

Shuman DA, Wanner GA, Klumb RA, Stancill WJ (2007) 2006 Annual report. Pallid sturgeon population assessment and associated fish community monitoring for the Missouri River: segments 5 and 6. Prepared for the US Army Corps of Engineers Missouri River Recovery Program. US Fish and Wildlife Service, Great Plains Fish and Wildlife Management Assistance Office, Pierre, SD (available at www.fws.gov/greatplainsfishandwildlife/)

Snook VA, Peters EJ, Young LJ (2002) Movements and habitat use by hatchery-reared pallid sturgeon in the lower Platte River, Nebraska. Am Fish Soc Symp 28:161-174

Spindler BD (2008) Modeling spatial distribution and habitat associations for juvenile pallid sturgeon (Scaphirhynchus albus) in the Missouri River. MS thesis, South Dakota State University, Brookings, SD

Steffensen KD, Powell LA, Koch JD (2010) Assessment of

Editorial responsibility: Craig Paukert,

Columbia, Missouri, USA hatchery-reared pallid sturgeon survival in the lower Missouri River. N Am J Fish Manag 30:671-678

Threader RW, Pope RJ, Schaap PRH (1998) Development of a habitat suitability index model for lake sturgeon (Acipenser fulvescens). Report number H-07015.010012. Ontario Hydro, Toronto

USFWS (US Fish and Wildlife Service) (2006) Pallid sturgeon (Scaphirhynchus albus) range-wide stocking and augmentation plan. Prepared by the Pallid Sturgeon Recovery Team plan submitted to Region 6. US Fish and Wildlife Service, Denver, CO

> Wanner GA, Shuman DA, Willis DW (2007) Food habits of juvenile pallid sturgeon and adult shovelnose sturgeon in the Missouri River downstream of Fort Randall Dam, South Dakota. J Freshw Ecol 22:81-92

Welker TL, Drobish MR (eds) (2010) Pallid sturgeon population assessment program, Vol 1.5. US Army Corps of Engineers, Omaha District, Yankton, SD (available at www.moriverrecovery.org)

> Wentworth CK (1922) A scale of grade and class terms for cladistic sediments. J Geol 30:377-392

Submitted: June 1, 2011; Accepted: December 9, 2011

Proofs received from author(s): March 7, 2012 